\title{
The Development of Sino Indian Trade from the Perspective of "The Belt and Road Initiative"
}

\author{
Che Zilong ${ }^{1}$ \\ ${ }^{1}$ School of International Studies, Communication University of China, China \\ Correspondence: Che Zilong, School of International Studies, Communication University of China, China. Tel: \\ 13466306002. E-mail: czl195@163.com
}

Received: August 17, 2021; Accepted: September 4, 2021; Published: September 6, 2021

The research is financed by research funding from Communication University of China (Sino-Indian Crosscultural Business Access Policy Research CUC200T009、Study on South Asian Language Education and Planning CUC2019B048、Study on the China-India Publishing Industry AMRC2019-44).

\begin{abstract}
Since ancient times, the two ancient civilizations of China and India have had a long history of trade exchanges, and such trade exchanges have left an important mark in the history of Sino-India relations. Chronologically, this article takes the Sino-Indian trade exchanges as a research perspective to outline two thousand years of trade history between two countries. From the Sino-Indian Business Road that began in the Qin Dynasty and Han Dynasty to the origin of the Silk Road on which Zhang Qian went to the Western Regions as an envoy, explored the Sino-India-Tibet Road and Maritime Silk Road trade; analyzed the opium trade between China, Britain and India in modern times. At the same time, it uses the founding of People's Republic of China, the Sino-Indian War, the Belt and Road Initiative and the important events of the global epidemic as nodes to describe the development of Sino-Indian trade. In the long history, this kind of rich trade history also shows that China and India are more likely and should establish a better and more extensive trade cooperation relationship, and learn to effectively deal with the turmoil. This will provide reference for operating the trade activities between the two countries.
\end{abstract}

Keywords: China, India, trade, Silk Road, One Belt One Road

\section{Introduction}

China and India are both ancient civilizations and neighbors connected by mountains and rivers. The two sides have a long land border. The trade exchanges between China and India are also the most special exchanges of civilizations in the history of the world. It is witnessed in the long river of history. The era records changes and conveys trends.

\section{Ancient Sino-Indian Trade Exchanges}

\subsection{The Silk Road}

Since ancient times, trade and cultural exchanges have existed between the two ancient civilizations of China and India. As early as the early years of the Han Dynasty, there was a business road leading to South Asia and Southeast Asia in southwest China. This commercial road departs from Chengdu, Sichuan, and enters Myanmar via Dali, Tengchong, Yunnan and other places, and finally reaches the Assam region in northeastern India. There is a record in the "Han Shu" Nanyi Biography" that long before Zhang Qian's envoy to the Western Regions, trade between China and India existed, and this road is very likely to connect the earliest link between the two civilizations. However, most of the trade activities along this road were private traders, who did not receive sufficient official attention. It was not until Zhang Qian's envoy to the Western Regions that a new trade pattern began to appear.

Although Zhang Qian's journey to the Western Regions did not complete the military mission of uniting the Da Yue clan against the Huns in the end, he had a more detailed understanding of the geography, properties, customs, and customs of the countries in the Western Regions. When he traveled to the southeast of the body poison country, he learned that the body poison merchants were still buying and selling silk and other goods produced in the Central Plains. So when Zhang Qian made his second mission to the Western Regions, he took the rare treasures of the Central Plains to engage in exchange activities. Subsequently, according to the "Historical Records Dawan Biography", a batch of envoys were sent to South Asia and other countries, and envoys from various countries 
were also invited to visit the Central Plains. So far, the Silk Road from Chang'an to South Asia via Central Asia has been basically completed.

However, the Sino-Indian trade during this period was not for profit, but for political and diplomatic purposes such as promoting national prestige, sending emissaries to each other, and strengthening friendly exchanges. At the time when the economy of the Han Dynasty was booming and the national power was strong, although the body poison was not a vassal state of the Central Plains, the way of sending goods to the Central Plains was similar to paying tribute. In addition, the types of goods exchanged between the two countries are mostly exotic treasures with strong regional characteristics. To a certain extent, they only met the needs of feudal rulers and princes and nobles for luxury and enjoyment, but they were rarely spread among the people. (Note 1)

In addition, because ancient China had the attributes of a farming society, the natural economy was dominant, and foreign trade was relatively small. The feudal rulers often did not pay attention to the development of foreign trade; and because of the prosperity of the Han Dynasty at that time, the rich products were self-sufficient for food and clothing. It is easy to cause people to have the closed concept of "the heavens are as big as everything else", so the volume of Chinese private traders engaged in commerce between the two countries is not large. The above factors have all contributed to the small scale of China-India trade.

\subsection{Maritime Silk Road}

As early as the pre-Qin period, primitive navigation activities existed in the southeast coastal areas of China. At that time, the voyage ranged as far as the islands of the South Pacific, and its nautical operations were mainly to respond to the requirements of fishery production. In the Han Dynasty, Emperor Wu of the Han Dynasty conquered Southern Guangdong, the sea route to the South Asian continent was opened up, and the maritime Silk Road route had begun to take shape. After the development of the Wei and Jin Dynasties, the Maritime Silk Road showed prosperity in the Sui and Tang Dynasties, and reached its peak in the Yuan and Song Dynasties.

Before the Sui and Tang Dynasties, the main route of China's foreign trade was the land-based Silk Road. The Maritime Silk Road was only a supplement, and the proportion was not large. However, after the Sui and Tang Dynasties, the land Silk Road was blocked by the fighting in the Western Regions, and the Maritime Silk Road became more and more important. During the Yuan and Song dynasties, navigation technology developed by leaps and bounds; Guangzhou, Quanzhou and other places became important port cities; the scale of maritime foreign trade gradually expanded, and economic and trade activities to the east coast of India also prospered.

\subsection{Zheng He's Voyages to the West}

Zheng He's voyage to the West in the Ming Dynasty was another great feat in the history of Chinese navigation. Zheng He had a total of seven voyages before and after, the farthest he reached Africa and the coast of the Red Sea. In the context of the Ming Dynasty's long-term maritime embargo, China's foreign trade volume has been greatly reduced, and this time nautical activities have allowed foreign economic and trade activities to proceed again. Zheng He's voyages to the West established a route from the southeast coast of China to southwest India (now the port city of Kerala), which also created conditions for the expansion of trade between the two countries.

\section{Triangular Opium Trade between China, Britain and India in Modern Times}

\subsection{The whole Process of the Opium Trade from its Rise to its Decline}

After the Industrial Revolution, the British colonists targeted India and China, the two rich ancient civilizations. From the 18th to the 19th centuries, a large number of mechanized production of silk fabrics severely damaged India's agriculture and national handicraft industry, and the British successfully opened up the Indian market and established the East India Company in Kolkata. Subsequently, the British planned to repeat the same trick and open the door to China through the same trade method. However, this move was met with stubborn resistance from the policy of "closing the country" adopted by the Qing Dynasty. In 1757, the Qing government ordered the blockade of some ports for foreign trade. By 1842, Guangzhou became the only port of China's maritime foreign trade. Britain is still in a disadvantaged position in the trade with China since modern times, so the British used the criminal opium triangle trade to open the door of China.

The so-called opium triangle trade refers to the British dumping of industrialized textiles in India and forcing India to produce opium, then illegally trafficking the opium to China, poisoning the body and spirit of the Chinese people, and then snapping up Chinese tea and transporting it back to the UK. In this way, it circulates among the three countries of Britain, India and China, forming a triangular trade. The opium trade has brought serious disasters to the Chinese people, and it has met with strong resistance from the Chinese people. However, the British even legalized it by launching a war. In 1840, the first Opium War broke out, and China has since become a semicolonial and semi-feudal country. Since then, it no longer has trade autonomy, and the amount of opium exported 
to China has increased year by year. In 1857, the Second Opium War broke out, and in the same year India also broke out an anti-British national uprising. Britain granted the Indian national bourgeoisie privileges in the opium trade and induced it to cooperate with Britain.

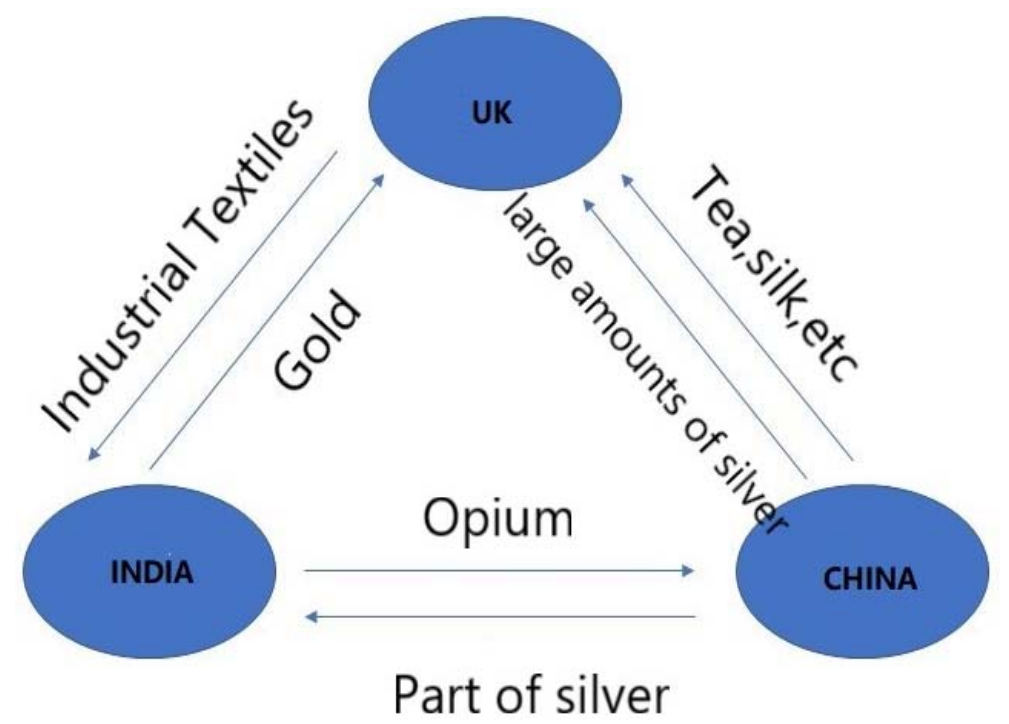

Figure 1. The so-called opium triangle trade

In 1858, the British coerced the Qing government into signing the Treaty on Trade Regulations to legalize the opium trade. Since then, the amount of opium exported to China has surged and reached its maximum in the 1880s. After 1884, due to the increase in opium poppy cultivation in China, the amount of opium imported began to decline. It was not until 1908 that the Chinese and British governments signed the Sino-British Anti-Smoking Treaty, and the opium trade that had been rampant for nearly a hundred years finally came to an end.

\subsection{Characteristics of Sino-Indian Trade during the Opium Trade}

During the opium trade, India produced opium under the coercion of the East India Company and smuggled it to port cities such as Guangzhou, China through port merchants. The commodities traded between China and India are mainly opium.

At the same time, China-India cotton yarn trade has also developed rapidly. As India's crude cotton yarn is a better raw material for hand-woven fabrics, China's imports of Indian cotton yarn have increased significantly. According to data records, the five-year average from 1894 to 1895 to 1898 to 1899 , cotton yarn exports to China amounted to 180.9 billion pounds, accounting for $94.3 \%$ of the total value of Indian cotton yarn exports of 191.8 million pounds, and the value was 1872 to 1873 . The annual growth rate is nearly 150 times, and its share in the total export value has risen by 27.7 percentage points (Note 2). This shows the development speed of cotton yarn trade.

\subsection{The Causes of the Opium Triangle Trade and its Impact on China and India}

The essential purpose of the opium trade initiated by the British colonists was to plunder China's wealth and complete the accumulation of primitive capital.

In modern times, several trade routes from Europe to the East have been controlled by the Ottoman Turk Empire. European countries need to pay high transfer fees to purchase Eastern goods. At the same time, out of the desire for gold, European capitalist countries have sent fleets to open up new routes to the east. Britain is one of these countries. After the British fleet arrived in the east, they tried their best to open the doors of China and India to dump their domestically produced industrial products. However, unlike India, China already had advanced handwoven and roasted ceramic technology in the Qing Dynasty, and did not have much demand for woolen fabrics and metal products produced by the United Kingdom. On the contrary, tea and raw silk were the opposite. But the demand in the UK is extremely high. Therefore, in the Sino-British trade in the 18th century, British businessmen always had a large trade deficit. In the end, the British colonists adopted a despicable trading method such as the opium trade to open the door of the Qing Dynasty.

The opium trade has brought great suffering to the Chinese people. Since its inception, a large amount of silver has flowed out to Britain and India, which has caused great damage to our country's fiscal revenue. In addition, 
the use of opium has also seriously damaged the physical and mental health of the Chinese people. Many Chinese people have lost their homes and died as a result of the use of opium. There are even people who take risks in order to buy opium and obtain money through crimes. As a result, the society has become turbulent. Once again, the Opium War that started due to the opium trade turned China into a semi-colonial and semi-feudal country. Since then, China has lost its sovereignty, and its endless wealth and treasures have been divided by Western powers. As far as India is concerned, the influence of the opium trade on it has two sides. Also as a victim of economic aggression, India's indigenous agriculture, industry and commerce have been strongly impacted by British commodities. However, India also participated in the economic aggression launched by Britain against China, and received a part of the reward for obeying and cooperating with Britain in opium production. These profits laid the foundation for the accumulation of primitive capital of the Indian bourgeoisie and further provided conditions for the establishment of modern enterprises.

\subsection{The role of "Country Merchant" in the Opium Triangle Trade}

From the end of the 17th century to the middle of the 19th century, the trade between India and China was called country merchant trade, and these merchants were called country merchants. At first, the East India Company was unable to completely prevent the activities of free merchants in the vast sea, so it controlled commercial activities by issuing concessions. In the beginning, the Qing government decree stipulated that the opium trade was an illegal trade, and the East India Company was not convenient for direct operation, so it was handed over to country merchants for smuggling. With the expansion of country merchant trade, the financial income of the East India Company continued to increase, and the East India Company also accumulated funds needed for trade with China. Originally, in the Sino-British trade, China had a long-term surplus and silver had flowed in. However, the opium smuggling trade of country merchants gradually changed this situation. As a result, a large amount of Chinese silver had flowed out, which exceeded the total value of Chinese silk tea exports. Since about 1817, the trade volume of country merchants accounted for $3 / 4$ of the total trade between Britain and British India, and by 1833 , the value of country merchant trade was three times the value of trade between Britain and China ( Note 3 ). Country merchants have an important position in the history of the Sino-British-Indian triangle opium trade.

\section{The Development of Sino-Indian Trade after the Founding of the "Belt and Road"}

\subsection{The development of Sino-Indian Trade after the Founding of the People's Republic of China}

During the outbreak of the real world war, normal international trade activities were carried out. With the exception of some international food aid, India's trade will almost appear to be open. It was not until the 40th birthday in the 19th century that trade exchanges gradually resumed. normal. However, such trade exchanges only lasted more than ten years. In 1962, the issue of cause led to the outbreak of the Sino-Indian War, and foreign trade activities were greatly affected. In the following 15 years, China confirmed that the affairs of the two sides could almost grasp the status of occurrence.

\subsection{Trade Development after the Sino-Indian War}

In 1977, the diplomatic relations between China and India at the ambassadorial level resumed serious and rapid development. The level of trade peaked in the following ten years:

Table 1. Sino-Indian Bilateral Trade Table (1977 1987) monetary Unit:1 billion RS

\begin{tabular}{ccccc}
\hline YEAR & $\begin{array}{c}\text { The amount of } \\
\text { bilateral trade }\end{array}$ & $\begin{array}{c}\text { The amount of India's } \\
\text { exports to China }\end{array}$ & $\begin{array}{c}\text { The amount of India's } \\
\text { imports from China }\end{array}$ & $\begin{array}{c}\text { India's trade } \\
\text { balance }\end{array}$ \\
\hline 1977 & 0.256 & 0.193 & 0.063 & 0.130 \\
1978 & 2.522 & 2.425 & 0.117 & 2.308 \\
1979 & 3.974 & 2.083 & 1.891 & 0.192 \\
1980 & 10.561 & 2.363 & 8.198 & -5.835 \\
1981 & 13.094 & 5.268 & 7.826 & -2.558 \\
1982 & 11.718 & 1.216 & 10.502 & -9.285 \\
1983 & 8.151 & 0.572 & 7.679 & -7.007 \\
1984 & 6.867 & 0.212 & 6.655 & -6.463 \\
1985 & 17.116 & 2.920 & 14.196 & -11.276 \\
1986 & 18.767 & 1.433 & 17.334 & -15.901 \\
1987 & 19.304 & 3.373 & 15.931 & -12.558 \\
\hline
\end{tabular}

Source: (Printed) "Financial Express" January 25, 1989 
Based on the above data, the total bilateral trade volume between China and India has increased nearly 75 times since the resumption of trade 10 years ago. However, despite the rapid development, the total trade volume between China and India is still very low, and each of them does not account for a high proportion of the total foreign trade of the two countries. In addition, there is also an imbalance in the development of trade between the two sides. After the resumption of trade, India only had a trade surplus for the three years from 1977 to 1979, and India had a deficit in bilateral trade for the following seven years.

From the perspective of the structure of trade products between China and India, the main commodities that India exports to China are raw cotton, pig iron, steel, barley, sucrose, tobacco, raw rubber, etc.; China's exports to India mainly include raw silk, chemical products, zinc, Machinery products, non-ferrous metals, etc. The rapid development of Sino-Indian trade during this period was inseparable from the adjustment of the economic and trade policies of the two countries. In 1978, Deng Xiaoping and other central leaders put forward the policy of reform and opening up. Before the "decade of catastrophe," China implemented a planned economy, and the countries of trade were limited to socialist countries such as the Soviet Union ( Note 4).

At that time, foreign trade was mainly managed by the state, and the degree of freedom was low. After the reform and opening up, China gradually established a socialist market-oriented economic system and carried out corresponding reforms to its foreign trade system, making it more adaptable to the international economic environment.

In the 1970s, India also transformed the past protectionist import substitution into an export-oriented trade strategy. However, India has a strong regional tendency in foreign trade. It has a relatively large amount of trade with capitalist countries such as Europe and the United States, and pays little attention to trade with developing countries. The policy changes of the two countries led to the rapid development of bilateral trade in the 1970s, but the total volume was still low.

\subsection{China-India Trade at the Turn of the Century}

After entering the 1990s, Sino-Indian trade has made new progress. With the end of the Cold War and the disintegration of the Soviet Union, external forces have gradually reduced the containment of South Asia, which has created new opportunities for the development of Sino-Indian trade. After the visit of former Indian Prime Minister Rajiv Gandhi to China in 1992, the diplomatic relations between the two countries have further developed, the border issues have been further eased, and Sino-Indian trade has also developed. In addition, as China's opening to the outside world has further deepened, the speed of India's economic development has increased, and the scale of trade between the two countries has also expanded.

However, there are still two problems in Sino-Indian trade: First of all, the commodity structures exported by China and India are relatively similar and not very complementary. This has resulted in the two countries being constantly in a state of competition in international trade. China and India share a high degree of similarity in the export industry structure. The main products exported by the two countries are mineral energy, chemical raw materials, agricultural products, and labor-intensive and industrial-intensive products, such as textiles, handicrafts, and chemical products. Wait. The larger electronic facilities and precision mechanical products that both countries need come from Western developed countries. Therefore, China and India are highly dependent on developed countries, while the degree of integration of bilateral trade between the two countries is not high. This similar import and export industrial structure weakens the trade cooperation between the two countries.

Secondly, India's trade protectionism is on the rise, and it has repeatedly imposed anti-dumping sanctions on China. Since India has always had a trade deficit in bilateral trade, and the products of its local companies are not as good as Chinese products in terms of quality and price, India has begun to impose trade sanctions on Chinese companies. According to the provisions of the World Trade Organization (WTO), in order to effectively protect their own interests, importing countries can impose anti-dumping duties on dumped goods to stop dumping ( Note 5). This provision was originally used to punish certain countries for non-compliance with international trade rules, but now it is used as an umbrella by trade protectionists. Since the 1880 s, India has been implementing anti-dumping policies against China, and this has undoubtedly been a huge blow to Chinese companies. Once punitive antidumping tariffs are imposed, companies will find it difficult to repeat them for more than five years or more than ten years. Enter the Indian market. In a sense, the anti-dumping policy has a strong anti-economic globalization color, which is extremely detrimental to bilateral trade.

\subsection{The Development of Sino-Indian Trade in the Era of Financial Crisis}

Affected by the financial crisis that swept the world in 2008, the total bilateral trade volume between China and India has declined. The two countries have adopted their own countermeasures to reduce losses, and they have 
achieved initial results. By the second half of 2009 , the two countries had weathered the cold winter of the financial crisis, once again strengthened business cooperation and exchanges, and the scale of trade reached a new high. As of 2009, the total bilateral trade reached US\$50 billion. China has become India's largest importer, while India has also become China's tenth largest trading partner. At the same time, bilateral trade has also shifted from a single commodity-based trade to a service-based trade, and cross-border business has also expanded to investment and financial cooperation. The economic and trade exchanges between the two countries are getting closer.

\section{The Development of Sino-Indian Trade from the Perspective of "One Belt One Road"}

Since the Chinese President Xi Jinping put forward the "One Belt One Road" construction concept in 2013, China has actively strengthened trade activities with South Asia based on the concept of open development, mutual benefit and win-win. A big opportunity.

\subsection{The Achievements of China-India Trade Development after the Implementation of the "One Belt One Road" Policy}

First, bilateral trade continues to deepen and the scale of trade is further expanded. As of 2015, the total bilateral trade in goods between China and India has exceeded the US\$70 billion mark ( Note 6). Secondly, the scale of bilateral investment has gradually shown an expanding trend. In 2014, China and India signed a cooperation agreement, planning to invest US $\$ 20$ billion in India's industry and infrastructure in the next five years. In addition to direct investment in Indian companies, Chinese investors also use greenfield investment to enter the Indian market. Many well-known Chinese companies such as Wanda, Xiaomi, and Huawei have set up overseas branches and built industrial parks in India. Third, the cooperation between China and India in the financial field has also developed rapidly. Bank of China, Industrial and Commercial Bank of China, etc. have entered India one after another, and the State Bank of India has also set up branches in China. The two countries also further discussed currency cooperation and cooperation in loan business, which further optimized the investment environment for investors. Third, the development of infrastructure construction in China and India has also achieved initial results. The scope of the construction industry covers many aspects such as electric power, automobiles, roads and railways, construction, energy transmission pipelines and so on. The Indian side has also set up a bonded zone for these Chinese enterprises in infrastructure construction, and jointly assumes risks through a Sino-Indian joint venture. Finally, the economic and technological cooperation between the two countries has gradually increased. China and India exchange what is needed, discuss and exchange with each other in modern agricultural technology, hightech industries, software service outsourcing, etc., and exchange and train IT talents.

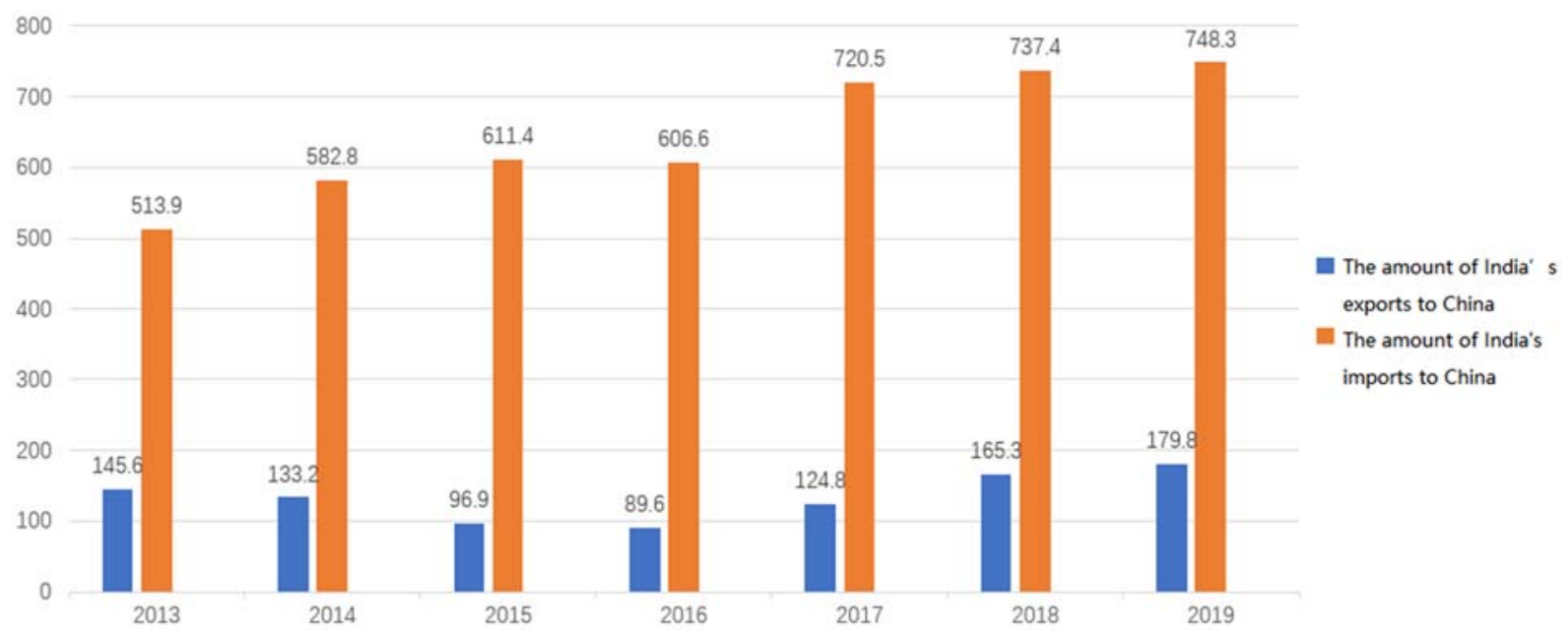

Figure 2. 2013-2019 China-India bilateral import and export trade (Unit:100 million dollars)

Data source: Indian Business Information Statistics Agency, Indian Ministry of Commerce

\subsection{The Impact of Multilateral Cooperation Mechanisms on Sino-Indian Trade}

The implementation of the "Belt and Road" policy is closely integrated with many existing international cooperation mechanisms, which has promoted the formation and development of regional economies. The cooperation mechanism of regional economies has further promoted the development of bilateral trade. Currently, 
the international cooperation mechanisms that China and India have joined include the BRICS, the Shanghai Cooperation Organization, the Group of 20, the Asian Infrastructure Investment Bank, and the India-ChinaBangladesh-Myanmar Economic Corridor. These cooperation mechanisms have promoted high-level dialogue between China and India at the macro level, as well as plans for future cooperation and development.

\subsection{Problems that Still Exist in China-India Bilateral Trade and Investment}

Although after the implementation of the "Belt and Road" policy, the trade exchanges between China and India have developed well, there have also been unavoidable trade frictions and collisions, which are manifested in the following aspects:

First of all, the economic and trade exchanges between the two countries are greatly affected by the political relations between the countries. Due to historical issues such as the China-India border, the political relations between the two countries are full of uncertainty, and economic and trade exchanges have also been greatly affected. In addition, India has always regarded Pakistan as a potential threat, and that China, which has a friendly relationship with Pakistan, will also harm India's interests, leading to the rise of the "China threat theory" in India, and the people and leaders of China's "Belt and Road" proposal from beginning to end. There is a certain degree of resistance. However, India does not want to miss the development opportunities brought about by the "Belt and Road" policy, so it only cooperates with China in some projects. After the military confrontation in the Donglang area on the China-India border in 2017, India's resistance to the "Belt and Road" initiative has reached a climax, and this factor has undoubtedly increased the barriers to bilateral trade.

In addition, due to India's "ideal of a great power" theory, India always regards China as a competitor rather than a partner of cooperation. After Prime Minister Modi came to power, he proposed the "Monsoon Plan" in 2014, intending to compete with China's "One Belt One Road" with his own external interconnection plan. However, because of the lack of clear development positioning, specific planning and implementation methods, the impact of this move is far less than China's "One Belt One Road" initiative. In addition, India is also actively participating in similar connectivity plans proposed by the United States, Japan and Russia to balance the influence of the "Belt and Road" plan.

Second, the rise of Indian tradeism caused by trade imbalances. Due to the lagging upgrading of the country's industrial structure and the lack of improvement in the economic development model, Indian products cannot compete with Chinese products in terms of quality and price, so there is a long-term trade deficit in bilateral trade. It is difficult to improve product quality and improve the mechanism in a short period of time. Therefore, trade protectionism has become the best means for India to temporarily alleviate this unfavorable situation. In recent years, in addition to frequent use of anti-dumping measures, India has also adopted measures such as import restrictions, tariffs, and trade remedies against some Chinese companies to suppress Chinese companies. However, due to China's imperfect anti-dumping response system, coupled with the lack of awareness of anti-dumping appeals and free-riding psychology of many Chinese companies, many companies have suffered heavy losses.

Finally, India imposes restrictions on the investment conditions of Chinese companies. India has restricted the direct investment of Chinese companies on the grounds of "national security", and has stepped up inspections on the investment access of Chinese companies in such industries as telecommunications, network outsourcing, and aviation. In addition, India also hopes that Chinese companies will enter the Indian market through a Sino-Indian joint venture rather than a sole Chinese investment, and it intends to allow Indian investors to gradually take control. In addition, the rigorous and cumbersome labor laws of India's commercial laws and the inefficiency of public officials have also made it impossible for many Chinese companies to defend their rights.

\section{India's Trade Protectionism in the Era of the Epidemic}

Since the outbreak of the novel coronavirus in 2020, the Indian economy has been hit hard by the epidemic, and domestic trade protectionism has risen further. On May 30, a mobile phone software called "Remove China Apps"was sought after among the Indian folks. This application is a one-click uninstall of all China-related apps in the mobile phone, and it has not only been online for 2 weeks, the download volume has exceeded One million, topped India's Google Play download list, and scored 4.8 points on Google Play, and received 140,000 comments. On June 29, the Indian Ministry of Information On the grounds of "and public order", 59 Chinese apps were banned, including Douyin International, WeChat, Weibo, UC browser and other software that have achieved great success in overseas markets, and more Chinese apps are included in strict supervision Range. So far, India has set off a climax of boycotting Chinese products from high-level government to the private sector, and attempted to use local programs to replace applications such as Douyin to meet the huge domestic market demand. On July 1, the Indian government made another move and no longer allowed any Chinese companies or joint ventures with Chinese companies to participate in road construction projects. The Ministry of Telecommunications (DoT) of 
India also formally cancelled the tender for "4G network installation, planning, testing and maintenance" initiated in March of this year on July 1, and decided to prohibit Chinese telecom suppliers from participating in the new tender. On the evening of September 2, the Indian government announced the ban on 118 Chinese apps. Such frequent violations of market rules and successive unreasonable policies restricting Chinese companies have played an extremely negative role in the mutually beneficial and win-win cooperation between China and India.

It is the global economic downturn triggered by the new crown epidemic and India's series of measures to block overseas countries that have made the situation of Indian companies even more difficult, and access to venture capital has been greatly reduced. Chinese companies have been somewhat disappointed in investment in India, which has also affected the international community. The sentiment of investing in India may be a wake-up call for the Indian government to adjust its policies in time to improve the business environment.

\section{Conclusion}

In the long history of the past, China and India have traded with each other, had brilliant brilliance and experienced the darkest moments. The diversified, mutually beneficial and win-win pattern and historical trend of today's world cannot be driven by individual consciousness to force a change. Only by not forgetting history, respecting each other, strengthening cooperation, maintaining world peace together, strengthening economic and cultural linkages, jointly coping with crises, abandoning differences, and carrying forward the past, can the two civilizations of China and India have a long history in the long history of seeking common ground while reserving differences.

\section{About the Author}

Che, Zilong is a lecture of School of International Studies, The Communication University of China. He received the BA. MA. from Peking University, P.hD from Mahatma Gandhi Antarrashtriya Hindi University. He worked for Pangoal Institution as a senior consultant. His research interest includes Sino-India Trade and Economy, Indian Language and Sino-Indian Culture. He has published more than 10 research articles in reputed journals, and has published books, has also presided the research projects related to intellectual Property Protection. E-mail address: czl195@163.com

\section{References}

McDonald, S., Sherman, R., \& Theirfelder, K. (Feb 2008). Asian growth and trade poles: India, China, and East and Southeast Asia. [J] World Development, 210-234. https://doi.org/10.1016/j.worlddev.2007.06.013

Qureshi, M. S., \& Wan, G. H. (Sep 2008). Trade expansion of China and India: Threat or opportunity. [J] World Economy, 1327-1350. https://doi.org/10.1111/j.1467-9701.2008.01131.x

Dolla, V. S. (2011). Journal of International Affairs [J]. Technology Trade In India-China Relations: Divergent Dynamics and Implications.

Li, M. Z., \& Gao, M. (2003). Strategies for Developing China's Software Industry [J]. Information Technologies and International Development. https://doi.org/10.1162/itid.2003.1.1.61

Kumar, N., \& Sita, S. (June 2019). Future of India-China Relations: A Key Role to the Global, Economy [C] International Conference on Management Science and Engineering Management, Springer, 510-522. https://doi.org/10.1007/978-3-030-21255-1_39

\section{Notes}

Note 1. "Historical Records" Volume 123 "Da Wan Biography", Beijing: Zhonghua Book Company 1959 Edition, p. 3170

Note 2. Yan Zhongping: "Chinese Cotton Textile History Draft", The Commercial Press, December 2011, page 70.

Note 3. Fang De Neighbors, "Hong Kong Foot Merchants and the Opium War", Journal of Beijing Normal University, No. 6, 1990.

Note 4. Cheng Jianjun, "Comparison of Sino-Indian Foreign Trade and Bilateral Trade Prospects", South Asian Studies Quarterly, Issue 1, 1990.

Note 5. Tang Pengqi, "The Reasons for India's Anti-dumping against Chinese Commodities", South Asian Research Quarterly, Issue 1, 2002.

Note 6. Data source: Indian Business Information Statistics Agency, Indian Ministry of Commerce. 


\section{Copyrights}

Copyright for this article is retained by the author(s), with first publication rights granted to the journal.

This is an open-access article distributed under the terms and conditions of the Creative Commons Attribution license (http://creativecommons.org/licenses/by/4.0/). 